\title{
Analisis Video Dislikes to VideoViewers Ratio YouTube pada 5 Penghasilan YouTuber Tertinggi di Dunia 2021
}

\author{
Ni Putu Anggi Kawitri \\ anggikawitrii@gmail.com
}

\begin{abstract}
YouTube is a video sharing website created by three former PayPal employees in February 2005. This website allows users to upload, watch, and share videos. Most of the content on YouTube is uploaded by individuals, unregistered users can watch videos, while registered users can upload an unlimited number of videos. So that many content creators have sprung up such as Youtubers of various ages. The content they create is also diverse with this content they can earn extraordinary income. The 5 Highest Earning YouTubers in the World 2021, namely: Ryan's world, Dude Perfect, PewDiePie, DanTDM, Markiplier. The purpose of this study is to determine the credibility of the performance of the YouTube accounts of the 5 highest-earning YouTubers in the world in 2021. The method used for this research is a quantitative exploratory method. The results of this study indicate that Ryan's World gets the highest score for the ratio of Video Dislikes to Video Viewers. Meanwhile, Dude Perfect's Youtube account gets the lowest score for this ratio. So, in this study Ryan's World has a better credibility than the others.
\end{abstract}

\begin{abstract}
ABSTRAK
YouTube adalah sebuah situs web berbagi video yang dibuat oleh tiga mantan karyawan PayPal pada Februari 2005. Situs web ini memungkinkan pengguna mengunggah, menonton, dan berbagi video. Kebanyakan konten di YouTube diunggah oleh individu, pengguna tak terdaftar dapat menonton video, sementara pengguna terdaftar dapat mengunggah video dalam jumlah tak terbatas. Sehingga banyak konten creator bermunculan seperti Youtuber dari berbagai kalangan usia. Konten yang mereka buat pun beragam dengan konten tersebut mereka bisa mendapatkan penghasilan yang sangat luar biasa. Adapun 5 Penghasilan YouTuber Tertinggi di Dunia 2021, yaitu : Ryan's world, Dude Perfect, PewDiePie, DanTDM, Markiplier. Tujuan dari penelitian ini adalah mengetahui kredibilitas performa dari akun YouTube dari 5 YouTuber dengan penghasilan tertinggi di dunia 2021. Metode yang digunakan untuk penelitian ini yaitu metode eksploratif kuantitatif. Hasil dari penelitian ini menunjukan bahwa Ryan's World mendapatkan nilai tertinggi untuk rasio Video Dislikes to Video Viewers. Sedangkan akun Youtube Dude Perfect mendapatkan nilai terendah untuk rasio ini. Jadi, pada penelitian ini Ryan's World memiliki kredibilitas performa yang lebih baik dibandingkan dengan yang lainnya.
\end{abstract}


Keyword : Credibility Account YouTube ; Social Media YouTube ; Video Dislikes to Video Viewers Ratio ; Penghasilan YouTuber Tertinggi di Dunia 2021.

\section{PENDAHULUAN}

Teknologi informasi dan komunikasi saat ini telah berkembang dengan pesat, hal ini membuat semakin banyak jenis aplikasi sosial media yang muncul dengan fitur dan fungsi yang berbedabeda. Salah satu aplikasi sosial media yang sering digunakan dan memiliki pengaruh besar adalah YouTube. Penelitian ini dilakukan dengan tujuan untuk menemukan rasio-rasio yang terdapat pada akun YouTube. Rasio-rasio ini yang nantinya akan digunakan untuk mengukur performa sebuah akun secara matematis. Penelitian ini dilakukan dengan menggunakan metode ekploratif untuk menemukan variabel-variabel yang terdapat pada akun YouTube. Variabel tersebut yang nantinya akan dibandingkan dan disandingkan untuk diuji relevansinya sehingga menjadi rasio yang relevan. Rasio yang relevan akan digunakan untuk menilai performa setiap akun yang ada pada sosial media YouTube. Hasil dari penelitian sosial media youtube ini menunjukan bahwa terdapat 6 variabel, variabel tersebut diantaranya yaitu post, subscriber, likes, dislikes, viewers, comments. Keenam variabel tersebut yang nantinya akan dibandingkan dan disandingkan sehingga menemukan 10 rasio yang relevan. Manfaat yang dapat diambil dari penelitian ini yaitu kedepannya dapat menilai, mengukur serta membandingkan kredebilitas dari setiap akun youtube dengan mudah menggunakan 10 rasio yang telah ditemukan. (Hendika Permana 2021).

Penelitian ini menggunakan metode eksploratif kuantitatif(Sidiq and Hastuti 2021), dan akan menghitung menggunakan rasio-rasio yang ada pada YouTube. Penelitian ini hanya berfokus untuk menghitung kredibilitas Video Dislikes to Video Viewers Ratio pada 5 Penghasilan YouTuber Tertinggi di Dunia 2021("Referensi 5 Penghasilan Youtuber Tertinggi Di Dunia 2021," n.d.). Adapun 5 Penghasilan YouTuber Tertinggi di Dunia 2021, diantaranya yaitu: Ryan's world, Dude Perfect, PewDiePie, DanTDM, Markiplier("Penelitian Ini Hanya Berfokus Untuk Menghitung Kredibilitas Video Dislikes to Video Viewers Ratio Pada 5 Penghasilan YouTuber Tertinggi Di Dunia 2021," n.d.). Tujuan dari penelitian ini adalah mengetahui kredibilitas performa dari akun Youtube 5 Penghasilan YouTuber Tertinggi di Dunia 2021 menggunakan Video Dislikes to Video Viewers Ratio.

\section{TINJAUAN PUSTAKA}

Internet bukan merupakan hal yang awam di era digital seperti ini, hampir disetiap kalangan dunia dapat mengakses internet dengan mudah. Dengan akses internet yang mudah didapatkan hampir seluruh kalangan masyarakat di Indonesia, membuat masyarakat mudah mengakses media sosial yang tersedia didalam internet. Salah satu media yang menyediakan tontonan atau video dengan berbasis internet adalah Youtube. Youtube berdiri sejak tahun 2005, namun baru populer dan dapat diakses oleh masyarakat Indonesia secara luas dalam beberapa tahun terakhir. Didalam youtube terdapat data-data mengenai aktivitas didalam youtube itu sendiri, terutama adalah data mengenai channel youtube yang memiliki jumlah subscriber, total views, dan lain-lain. Didalam 
jurnal ini kami akan membahas mengenai grade yang didapatkan oleh suatu channel youtube dengan dilakukannya pengolahan Big Data mengenai channel youtube. Metode penelitian yang dilakukan adalah metode penelitian deskriptif dimana data akan diolah untuk membuat deskripsi secara sistematis,faktual, serta akurat pada fakta atau sifat populasi tertentu. Penelitian bertujuan untuk menguji tingkat popularitas beberapa channel youtube dari banyaknya upload serta pelanggan dan juga banyaknya orang yang melihat video. Hasil penelitian menunjukan bahwa adanya tingkat popularitas (yang dinilai berdasarkan view, subscriber, dan upload) dari total 5001 channel youtube yang berbeda dapat yang mempunyai urutan sebagai berikut : (A++,A+,A,A,B+). (Sudarsono et al. 2020)

\section{METODE PENELITIAN}

Penelitian ini menggunakan metode eksploratif kuantitatif untuk mengetahui kredibilitas dari performa akun Youtube 5 Penghasilan YouTuber Tertinggi di Dunia 2021. Penelitian tipe eksploratif, bertujuan memperdalam pengetahuan dan mencari ide-ide baru mengenai suatu gejala tertentu, menggambarkan fenomena sosial, dan menjelaskan bagaimana terjadinya suatu fenomena sosial untuk merumuskan masalah secara lebih terperinci atau mengembangkan hipotesis bukan menguji hipotesis.(Mudjiyanto 2018)

Tujuan dari penelitian ini yaitu mengetahui nilai kredibillitas dari performa akun YouTube 5 Penghasilan YouTuber Tertinggi di Dunia 2021(“Tujuan Dari Penelitian Ini Yaitu Mengetahui Nilai Kredibillitas Dari Performa Akun YouTube 5 Penghasilan YouTuber Tertinggi Di Dunia 2021," n.d.). Ada beberapa langkah yang perlu dilakukan dalam penelitian ini, agar dapat menemukan peringkat pertama akun YouTube Penghasilan YouTuber Tertinggi di Dunia 2021. Langkah-langkah yang dilakukan pada penelitian ini, diantaranya yaitu :

\section{Melakukan Eksplorasi Pada Website Untuk Menentukan Objek yang Akan Dianalisa.}

Eksplorasi ini dilakukan pada beberapa halaman website yang menyediakan informasi mengenai objek yang akan di teliti. Setelah ekslorasi selesai dilakukan, sehingga ditemukan nama-nama akun Youtuber dengan penghasilan tinggi yang akan dijadikan objek analisa. Setelah melakukan eksplorasi pada halaman website, maka langkah selanjutnya yaitu mencari nama akun Youtube dari masing-masing Youtuber("Eksplorasi Ini Dilakukan Pada Beberapa Halaman Website Yang Menyediakan Informasi Mengenai Objek Yang Akan Di Teliti," n.d.). Pastikan semua Youtuber memiliki akun pada aplikasi sosial media Youtube. 


\section{Menghitung Nilai Rata-Rata Variable Dari 5 Penghasilan YouTuber Tertinggi di Dunia 2021.}

Pada langkah ini, peneliti menghitung nilai variable Video Dislikes dan Video Viewers. Variabel merupakan suatu yang bersikap itu berubah-ubah atau juga tidak tetap. Dapat juga didefinisikan ialah sebagai nilai yang mempunyai banyak varian, intinya itu bernilai banyak. Nah untuk lebih jelasnya mengenai variabel ini maka akan dipaparkan juga penjelasan mengenai variabel yang dikemukakan oleh para ahli.(Ibeng 2020). Untuk menghitung nilai rata-rata dari variabel Video Dislikes dan Video Viewers adalah dengan cara mengambil minimal 10 postingan kemudian di hitung sehingga menemukan nilai rata-rata dari masing-masing variabel("Untuk Menghitung Nilai Rata," n.d.).

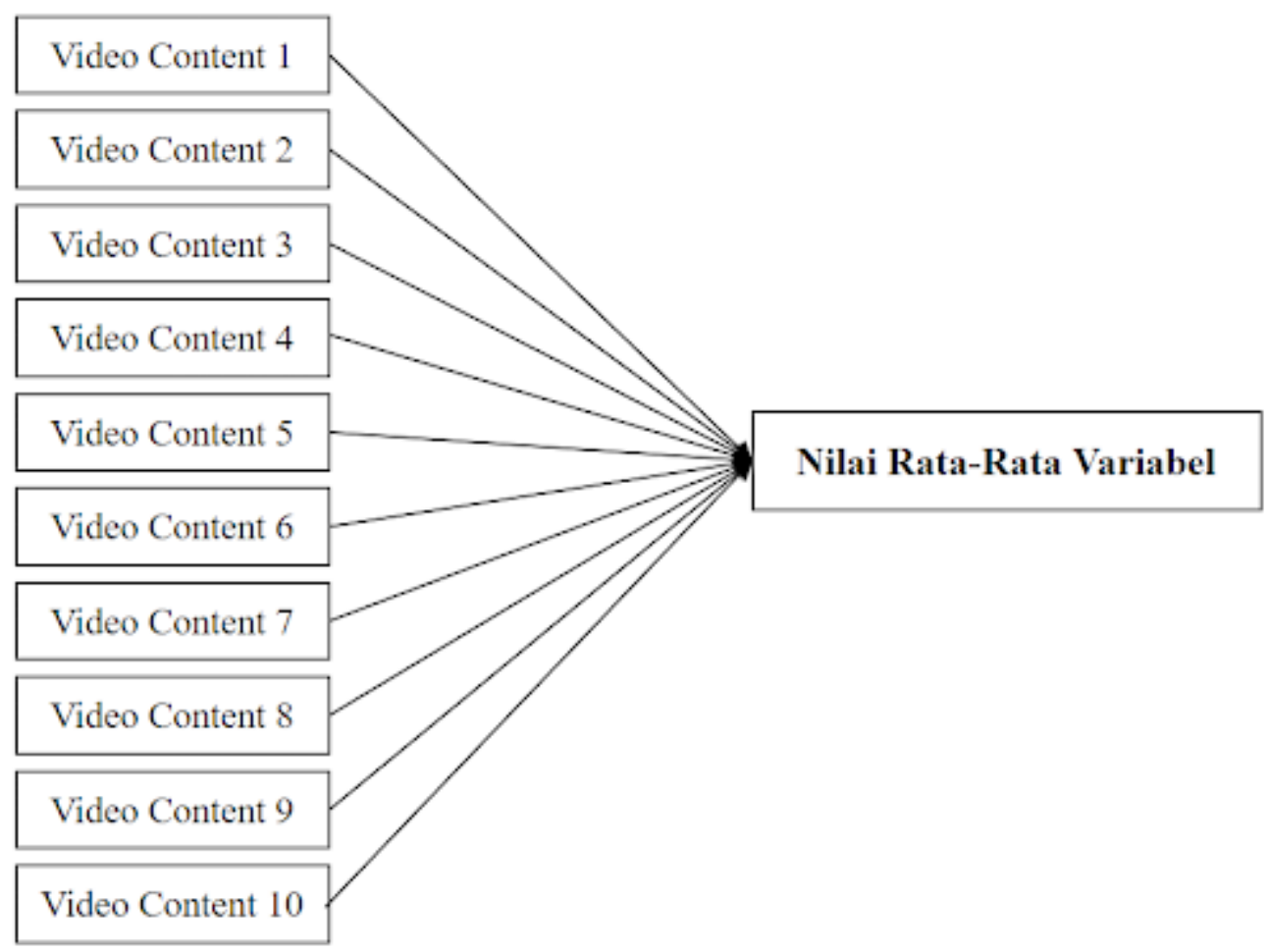

\section{Menghitung Nilai Kredibilitas Rasio}

Untuk menghitung nilai kredibilitas dari Video Dislikes to Video Viewers ratio, peneliti menggunakan cara membagi nilai variabel pertama dengan nilai variabel kedua. Jika video dislikes memiliki nilai 100 dan video views memiliki nilai 200, maka cara menghitungnya yaitu $100: 200=0,5$. Dengan begitu nilai dari Video Dislikes to Video Viewers ratio adalah 0,5. 


\section{Menentukan Peringkat Pada Akun Youtube}

Langkah terakhir yang dilakukan pada penelitian ini yaitu menentukan peringkat pada masing-masing rasio yang ada. Pada penentuan peringkat perlu melihat karakteristik dari rasio yang di teliti. Jika karakteristik rasio merupakan rendah, maka objek yang memiliki nilai terendah akan mendapatkan angka 5 dan objek yang memiliki nilai tertinggi akan mendapatkan angka 1 . Namun jika rasio memiliki karakteritik tinggi maka objek yang mendapatkan nilai tinggi akan mendapatkan angka 5 dan objek yang mendapatkan nilai terendah akan mendapatkan angka 1. Setelah mendapatkan hasil kredibilitas ratio maka dapat disimpulkan objek yang mana mendapatkan peringkat 1 sampai dengan peringkat 5 .

\section{HASIL DAN PEMBAHASAN}

Akun YouTube dari 5 YouTuber dengan penghasilan tertinggi di dunia 2021, diantaranya:

\section{Ryan's world}

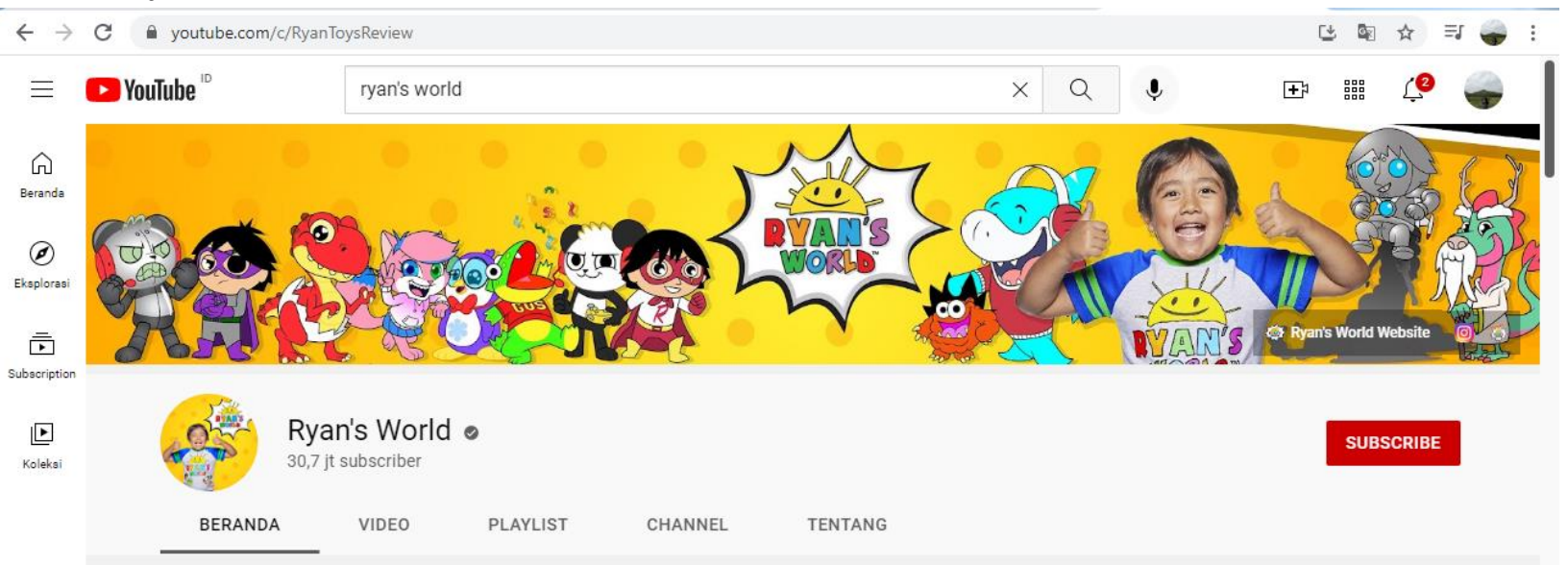

Gambar 1. akun YouTube Ryan's world Sumber : https://www.youtube.com/c/RyanToysReview (akses pada 21-10-2021) 


\section{DudePerfect}

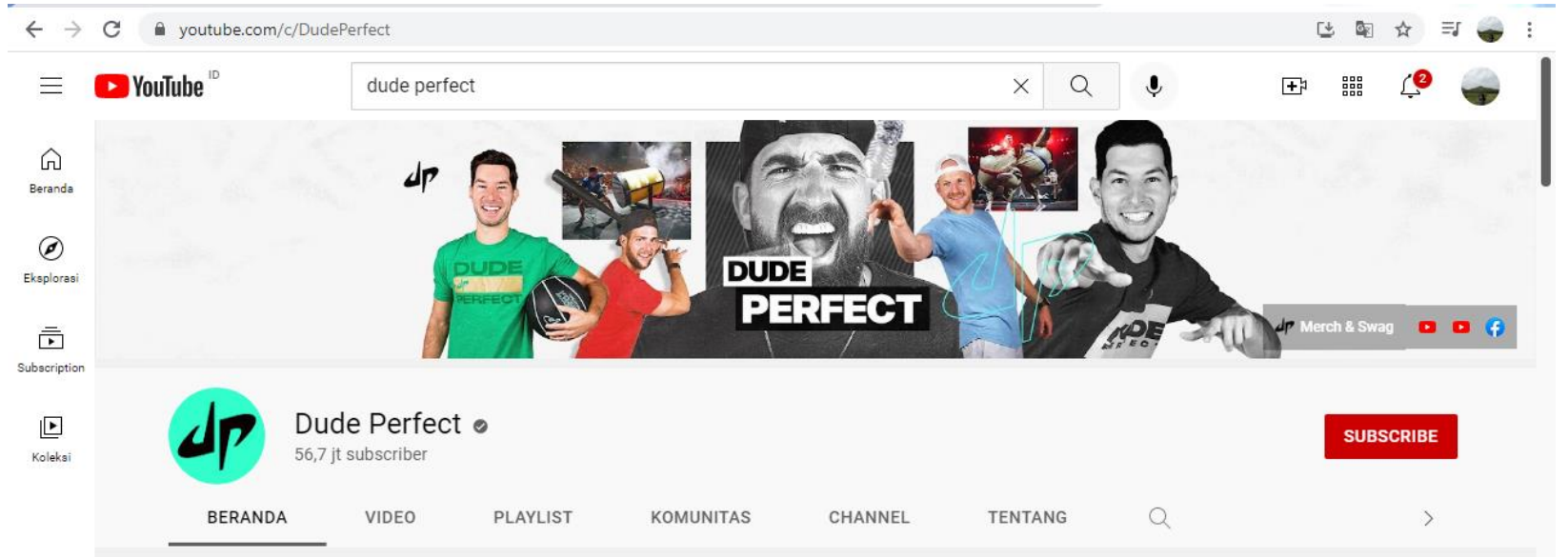

Gambar 2. akun YouTube Dude Perfect

Sumber : https://www.youtube.com/c/DudePerfect (akses pada 21-10-2021)

\section{PewDiePie}

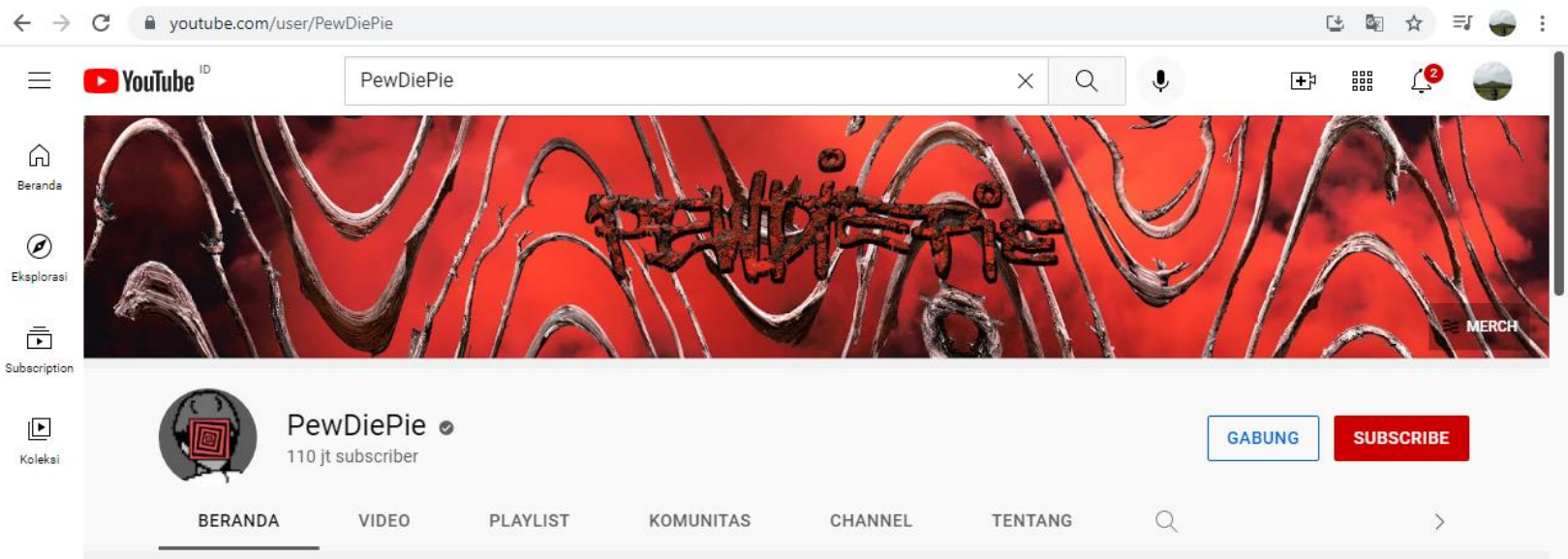

Gambar 3. akun YouTube PewDiePie

Sumber : https://www.youtube.com/user/PewDiePie (akses pada 21-10-2021) 


\section{DanTDM}

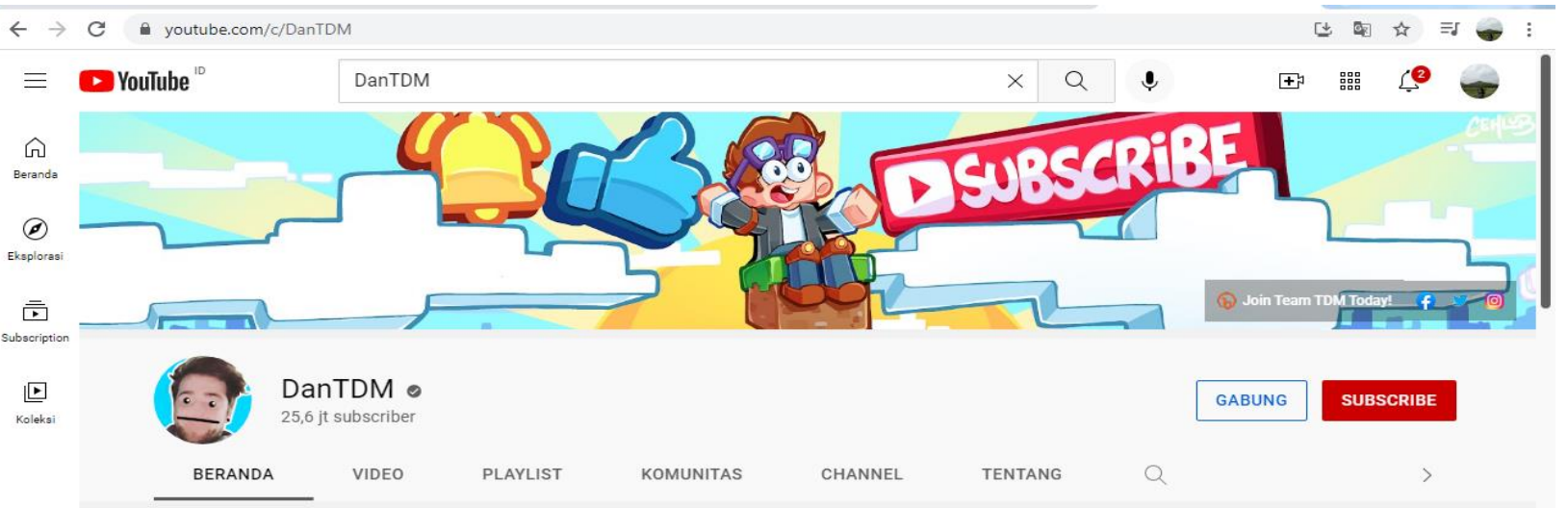

Gambar 4. akun YouTube DanTDM

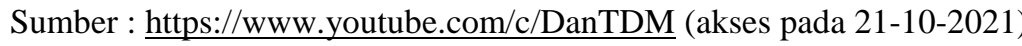

\section{Markiplier}

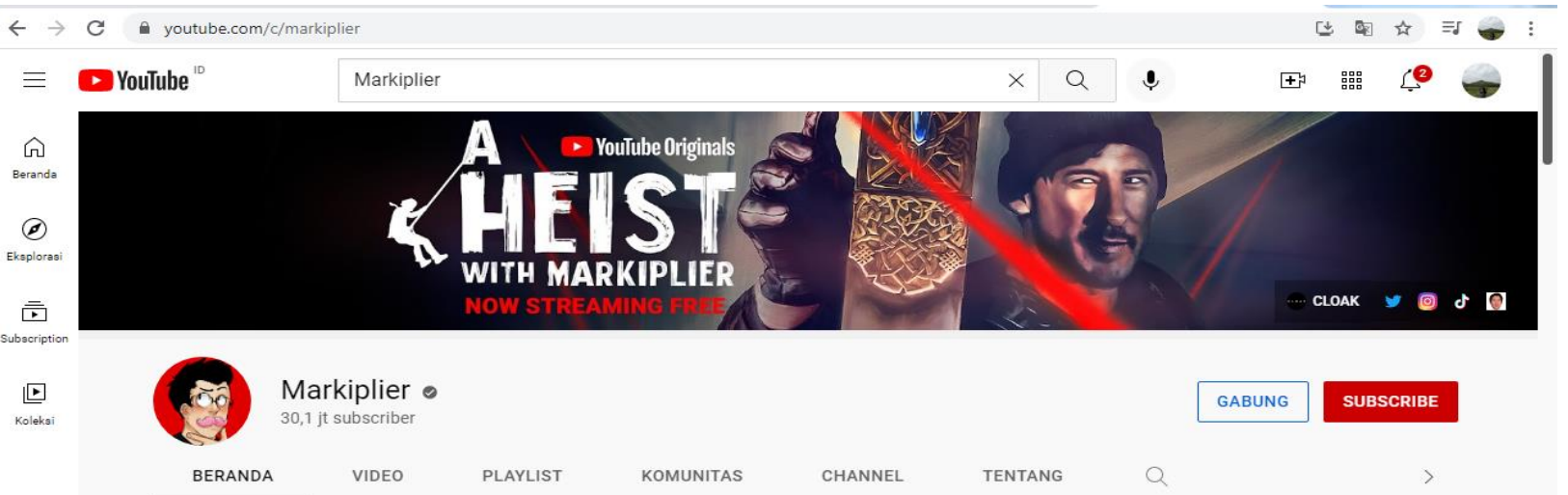

Gambar 5. akun YouTube Markiplier

Sumber : https://www.youtube.com/c/markiplier (akses pada 21-10-2021)

Dari kelima Channel YouTube 5 YouTuber dengan penghasilan tertinggi di dunia 2021, peneliti menemukan nilai dari masing-masing variabel yang ada untuk menghitung rasio Video Dislikes to Video Viewers dari setiap channel. Pada akun YouTube terdapat 6 variabel, diantaranya yaitu :
1. Likes

2. Post

3. Subscriber

4. Dislikes

5. Comments

6. Viewers

Dari keenam variabel tersebut peneliti hanya fokus untuk menemukan hasil dari 2 variabel, yaitu : 


\section{Video Dislikes}

\section{Video Viewers}

Dari keenam variabel tersebut kemudian dianalisa sehingga menemukan nilai rata-rata dari variable Video Dislikes dan variable Video Viewers. Untuk menghitung nilai ratarata dari variabel Video Dislikes dan variable Video Viewers yaitu dengan cara mengambil minimal 10 postingan kemudian di hitung sehingga menemukan nilai ratarata dari masing-masing variabel. Berikut merupakan tabel nilai rata-rata dari masingmasing Youtuber dengan penghasilan tertinggi di dunia 2021, yaitu :

Tabel 1. Analisa Nilai Rata-Rata Nilai Variabel Video Dislikes dan Video Viewers akun YouTube Ryan's world

\begin{tabular}{|c|c|c|}
\hline No & Video Dislikes & Video Viewers \\
\hline 1 & 175 & 109,997 \\
\hline 2 & 1,000 & 723,547 \\
\hline 3 & 6,700 & $3,673,895$ \\
\hline 4 & 907 & $1,001,868$ \\
\hline 5 & 1,000 & 709,808 \\
\hline 6 & 1,200 & $1,048,730$ \\
\hline 7 & 751 & 741,124 \\
\hline 8 & 698 & 545,766 \\
\hline 9 & 438 & 330,196 \\
\hline 10 & 4,100 & $4,642,831$ \\
\hline Total & $\mathbf{1 6 9 6 . 9}$ & $\mathbf{1 , 3 5 2 , 7 7 6}$ \\
\hline
\end{tabular}

Tabel 2. Analisa Nilai Rata-Rata Nilai Variabel Video Dislikes dan Video Viewers akun YouTube Dude Perfect

\begin{tabular}{|c|c|c|}
\hline No & Video Dislikes & Video Viewers \\
\hline 1 & 3,700 & $5,431,837$ \\
\hline 2 & 7,500 & $10,820,175$ \\
\hline 3 & 2,700 & $8,703,602$ \\
\hline 4 & 5,300 & $9,623,799$ \\
\hline 5 & 3,400 & $7,906,553$ \\
\hline 6 & 7,100 & $5,488,996$ \\
\hline 7 & 11,000 & $13,350,220$ \\
\hline 8 & 6,600 & $11,251,849$ \\
\hline 9 & 8,600 & $18,980,637$ \\
\hline 10 & 7,500 & $15,419,517$ \\
\hline Total & $\mathbf{6 , 3 4 0}$ & $\mathbf{1 0 , 6 9 7 , 7 1 9}$ \\
\hline
\end{tabular}

Sumber : Pengolah Data Excel 
Tabel 3. Analisa Nilai Rata-Rata Nilai Variabel Video Dislikes dan Video Viewers akun YouTube PewDiePie

\begin{tabular}{|c|c|c|}
\hline No & Video Dislikes & Video Viewers \\
\hline 1 & 1,000 & $1,235,074$ \\
\hline 2 & 1,800 & $3,027,716$ \\
\hline 3 & 2,200 & $2,985,655$ \\
\hline 4 & 818 & $4,113,303$ \\
\hline 5 & 3,500 & $3,137,631$ \\
\hline 6 & 2,800 & $4,279,837$ \\
\hline 7 & 2,900 & $2,924,727$ \\
\hline 8 & 4,500 & $4,265,799$ \\
\hline 9 & 1,400 & $1,510,198$ \\
\hline 10 & 1,800 & $2,299,240$ \\
\hline Total & $\mathbf{2 , 2 7 2}$ & $\mathbf{2 , 9 7 7 , 9 1 8}$ \\
\hline
\end{tabular}

Sumber : Pengolah Data Excel

Tabel 4. Analisa Nilai Rata-Rata Nilai Variabel Video Dislikes dan Video Viewers akun YouTube DanTDM

\begin{tabular}{|c|c|c|}
\hline No & Video Dislikes & Video Viewers \\
\hline 1 & 230 & 436,932 \\
\hline 2 & 2,700 & $5,475,507$ \\
\hline 3 & 363 & $1,046,850$ \\
\hline 4 & 1,000 & $2,306,055$ \\
\hline 5 & 416 & $1,269,781$ \\
\hline 6 & 832 & $2,178,539$ \\
\hline 7 & 259 & 931,536 \\
\hline 8 & 442 & $1,135,870$ \\
\hline 9 & 493 & $1,257,103$ \\
\hline 10 & 400 & $1,240,848$ \\
\hline Total & $\mathbf{7 1 3 . 5}$ & $\mathbf{1 , 7 2 7 , 9 0 2}$ \\
\hline
\end{tabular}

Sumber : Pengolah Data Excel 
Tabel 5. Analisa Nilai Rata-Rata Nilai Variabel Video Dislikes dan Video Viewers akun YouTube Markiplie

\begin{tabular}{|c|c|c|}
\hline No & Video Dislikes & Video Viewers \\
\hline 1 & 411 & 992,165 \\
\hline 2 & 575 & $2,006,508$ \\
\hline 3 & 982 & $2,156,654$ \\
\hline 4 & 978 & $2,514,311$ \\
\hline 5 & 782 & $2,570,795$ \\
\hline 6 & 1,400 & $3,461,185$ \\
\hline 7 & 1,600 & $2,349,125$ \\
\hline 8 & 946 & $2,068,407$ \\
\hline 9 & 594 & $1,917,561$ \\
\hline 10 & 379 & $1,209,976$ \\
\hline Total & $\mathbf{8 6 4 . 7}$ & $\mathbf{2 , 1 2 4 , 6 6 9}$ \\
\hline
\end{tabular}

Sumber : Pengolah Data Excel

Setelah menghitung nilai rata-rata tersebut, maka akan menemukan hasil akhir nilai ratarata dari variable Video Dislikes dan Video Viewers.

Tabel 6. Nilai Variabel Pada akun YouTube 5 YouTuber dengan penghasilan tertinggi di dunia 2021.

\begin{tabular}{|c|c|c|c|c|c|}
\hline Ryan's World & Dude Perfect & PewDiePie & DanTDM & Markiplier & Variable \\
\hline 1696.9 & 6,340 & 2,272 & 713.5 & 864.7 & Dislikes \\
\hline $1,352,776$ & $10,697,719$ & $2,977,918$ & $1,727,902$ & $2,124,669$ & Viewers \\
\hline
\end{tabular}

Sumber : Pengolah Data Excel

Pada akun YouTube terdapat 11 rasio yang relevan digunakan untuk mengukur kredibilitas pada masing-masing akun. Namun pada penelitian kali ini hanya berfokus untuk menghitung Video Dislikes to Video Viewers Ratio. Untuk menghitung kredibilitas dari masing-masing akun Youtube setiap Youtuber, peneliti menghitung dengan cara : variabel 1 akan dibagi dengan variabel 2, sehingga ditemukan hasil analisisa dari rasio tersebut.

Tabel 7. Hasil Perhitungan Rasio Akun Youtube

\begin{tabular}{|c|c|}
\hline Nama & Total \\
\hline Ryan's World & 0.001254384 \\
\hline Dude Perfect & 0.00059265 \\
\hline PewDiePie & 0.000762949 \\
\hline DanTDM & 0.000412929 \\
\hline Markiplier & 0.000406981 \\
\hline
\end{tabular}

Sumber : Pengolah Data Excel 
Video Dislikes to Video Viewers memiliki karakteristik yang tinggi, artinya semakin tinggi nilai yang dihasilkan maka semakin baik kredibilitas dari performa akun tersebut. Untuk memberikan peringkat pada masing-masing Youtuber, peneliti memberikan angka 5 kepada akun Youtube yang mendapatkan nilai tertinggi dan angka 1 untuk akun Youtube yang mendapatkan nilai terendah. Berikut merupakan tabel urutan nilai yang dihasilkan oleh masing-masing akun Youtube.

Tabel 8. Nilai Rasio Akun Youtuber YouTuber dengan penghasilan tertinggi di dunia 2021

\begin{tabular}{|c|c|c|}
\hline Nama & Total & Peringkat \\
\hline Ryan's World & 0.001254384 & 5 \\
\hline Dude Perfect & 0.00059265 & 1 \\
\hline PewDiePie & 0.000762949 & 4 \\
\hline DanTDM & 0.000412929 & 3 \\
\hline Markiplier & 0.000406981 & 2 \\
\hline
\end{tabular}

Sumber : Pengolah Data Excel

Dari Tabel Nilai Rasio Akun Youtuber YouTuber dengan penghasilan tertinggi di dunia 2021 dapat simpulkan bahwa Ryan's World mendapatkan nilai tertinggi untuk rasio Video Dislikes to Video Viewers. Sedangkan akun Youtube Dude Perfect mendapatkan nilai terendah untuk rasio ini. Jadi, pada penelitian ini Ryan's World memiliki kredibilitas performa yang lebih baik dibandingkan dengan yang lainnya.

\section{KESIMPULAN}

Tujuan dari penelitian ini adalah mengetahui kredibilitas performa dari akun YouTube dari 5 YouTuber dengan penghasilan tertinggi di dunia 2021 menggunakan Video Dislikes to Video Viewers diantaranya yaitu: Ryan's World, Dude Perfect, PewDiePie, DanTDM, Markiplier. Dari kelima tersebut dapat disimpulkan bahwa :

1. Peringkat pertama diraih oleh Dude Perfect dengan nilai tertinggi yaitu 0.00059265

2. Peringkat kedua diraih oleh Markiplier dengan nilai 0.000406981

3. Peringkat ketiga diraih oleh DanTDM dengan nilai 0.000412929

4. Peringkat keempat diraih oleh PewDiePie dengan nilai 0.000762949

5. Peringkat kelima diraih oleh Ryan's World dengan nilai tertinggi yaitu 0.001254384 


\section{DAFTAR PUSTAKA}

"Eksplorasi Ini Dilakukan Pada Beberapa Halaman Website Yang Menyediakan Informasi Mengenai Objek Yang Akan Di Teliti.” n.d.

Hendika Permana, I Putu. 2021. "Analisis Rasio Pada Akun Youtube Untuk Penelitian Kualitatif Menggunakan Metode Ekploratif.” Jurnal Ilmiah Media Sisfo 15 (1): 40. https://doi.org/10.33998/mediasisfo.2021.15.1.970.

Ibeng, Parta. 2020. "Pengertian Variabel, Jenis, Contoh Dan Menurut Para Ahli." Www.Pendidikan.Co.Id. 2020.

Mudjiyanto, Bambang. 2018. “TIPE PENELITIAN EKSPLORATIF KOMUNIKASI.” Jurnal Studi Komunikasi Dan Media 22 (1). https://doi.org/10.31445/jskm.2018.220105.

"Penelitian Ini Hanya Berfokus Untuk Menghitung Kredibilitas Video Dislikes to Video Viewers Ratio Pada 5 Penghasilan YouTuber Tertinggi Di Dunia 2021.” n.d.

“Referensi 5 Penghasilan Youtuber Tertinggi Di Dunia 2021.” n.d.

Sidiq, R, and P Hastuti. 2021. "Persepsi Guru Sejarah Wilayah Sumatra Utara Terhadap Pendampingan Program Pengembangan Media Pembelajaran Interaktif.” Prosiding Seminar Nasional Hasil ..., no. November.

Sudarsono, Bernadus Gunawan, Rahma Saputra, Ferik Utomo, and Christian Wijaya. 2020. "Segmentasi Popularitas Akun Youtube Menggunakan Metode ID3." JBASE - Journal of Business and Audit Information Systems 3 (2). https://doi.org/10.30813/jbase.v3i2.2269.

“Tujuan Dari Penelitian Ini Yaitu Mengetahui Nilai Kredibillitas Dari Performa Akun YouTube 5 Penghasilan YouTuber Tertinggi Di Dunia 2021.” n.d.

“Untuk Menghitung Nilai Rata.” n.d. 